\title{
УДК 691:620.174
}

\section{EFFECTIVE SYSTEM FOR STRENGTHENING OF STRUCTURES ЭФФЕКТИВНАЯ СИСТЕМА УСИЛЕНИЯ КОНСТРУКЦИЙ}

Varlamov A.А./Варламов А.А. c.t.s., prof/к.m.н., проф.

Gavrilov V.B. / Гаврилов В.Б. c.t.s., as.prof. / к.m.н., доu.

Vedenyev A.V. / Веденёв A.B. master student / магистрант

Magnitogorsk StateTtechnical University,Magnitogorsk, Lenin Ave 27,455000 Магнитогорский государственный технический университет. Магнитогорск, пр. Ленина 27,

Аннотация. В работе рассматривается вопрос усиления изгибаемых железобетонных элементов. Усиление элементов предлагается выполнять современными углепластиклвыми волокнами системы MBrace концерна BASF. Для оценки возможности усиления изгибаемых элементов, изготовленных из местных материалов, были выполнены испытания железобетонных перемычек. Было изготовлено пять партий образиов. Одна партия без усиления. Одна с усилением только растянутой части сечения. Две партии с усилением ламелью нормальных и наклонных сечений. Одна партия с усилением ламелью и холстом. Приведены результаты испытаний. Выявлена новая расчетная схема разрушения балок. Приведено сравнение опытных и теоретических разрушающих усилий. Проведен анализ испьтаний и сделаны выводы.

Ключевые слова: усиление перемычек, система усиления МВгасе, углепластик, изгибаемый элемент, испытания.

\section{Вступление.}

В последние 10-15 лет в России значительно увеличился объем работ по реконструкции зданий различного назначения с целью продления их жизненного цикла. Для железобетонных конструкций разработано множество технических решений по их усилению: наращивание сечений, изменение расчетной схемы конструкций с целью перераспределения нагрузок, устройство обойм и пр., опубликовано множество рекомендаций, конструктивных решений и методик проектирования ремонта и усиления строительных элементов [1-10]. В настоящее время как у нас в стране, так и за рубежом для усиления различных конструкций широко применяют композиционные материалы на основе стекло- и углеродного волокон. Эффективность применения этих материалов для усиления конструкций связана с тем, что их прочностные и деформативные характеристики существенно превышают аналогичные характеристик типовых материалов (металл, бетон, раствор), применяемых для усиления конструкций. Углепластики обладают высокими прочностными свойствами (прочность на растяжение до 3500 МПа, модуль упругости до $3 \times 10^{5}$ МПа). Это предопределяет незначительную толщину накладок (не более $2 \div 3$ мм) и снимает проблему сокращения полезной высоты помещений, что особенно существенно в жилых зданиях. Кроме этого, удельный вес композиционных материалов в 4-5 раз меньше, чем у стали, их можно использовать для усиления любых по форме конструкций. Эти материалы 
имеют малую толщину (от 0,1 до 2 мм), легко поддаются предварительному напряжению, а при необходимости - легко ремонтируются.

Усиление дефектных конструкций с целью восстановления потерь несущей способности может осуществляться путем дополнительного внешнего армирования их углепластиковыми накладками. Приклеиваемые на поверхность железобетонных конструкций углеродные ленты дополняют существующую внутреннюю арматуру, снижая в ней напряжения до приемлемого уровня. Одновременно повышается жесткость конструкций и их трещиностойкость.

\section{Методика проведения испытаний.}

В рассматриваемой работе приведены результаты испытаний балок, усиленных с использованием системы MBrace концерна BASF. Работа выполнена по заданию концерна BASF. Для отработки методики по увеличению несущей способности по нормальным и наклонным сечениям в лабораторных условиях были проведены исследования на железобетонных перемычках размером 120x140x1600 мм.

Всего было испытано 10 перемычек по 5 разным схемам (рис.1- 5).
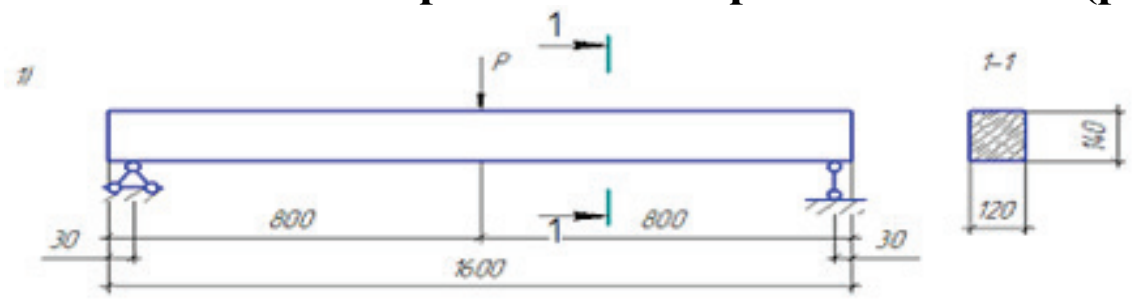

Рис.1. Схема испытания перемычек без усиления. Серия П-I

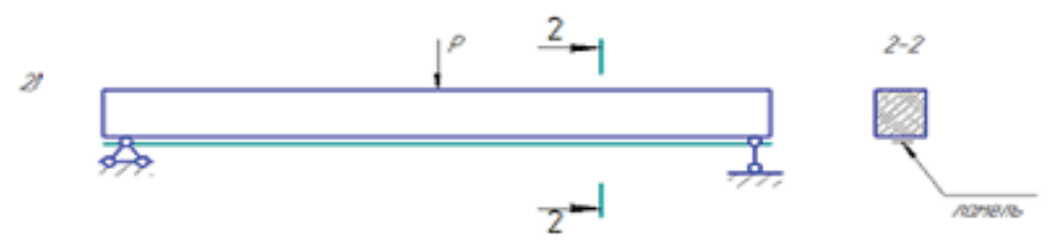

Рис.2. Схема испытания с усилением ламелью. Серия Пу-II
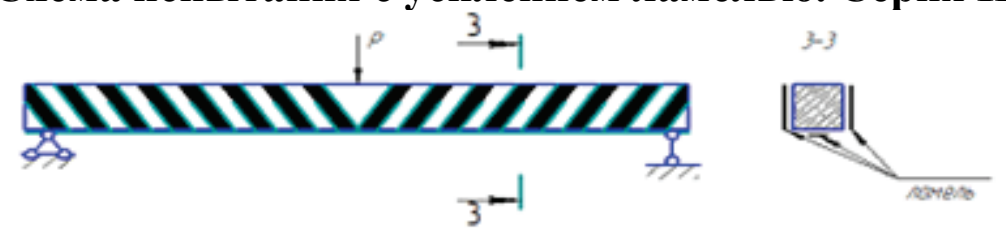

Рис.3. Схема с усилением по серии Пу-III

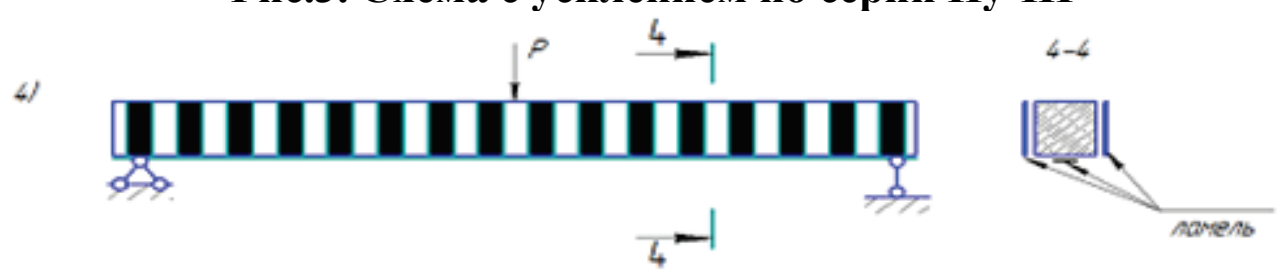

Рис.4. Схема с усилением ламелью (вариант 2). Серия Пу-IV

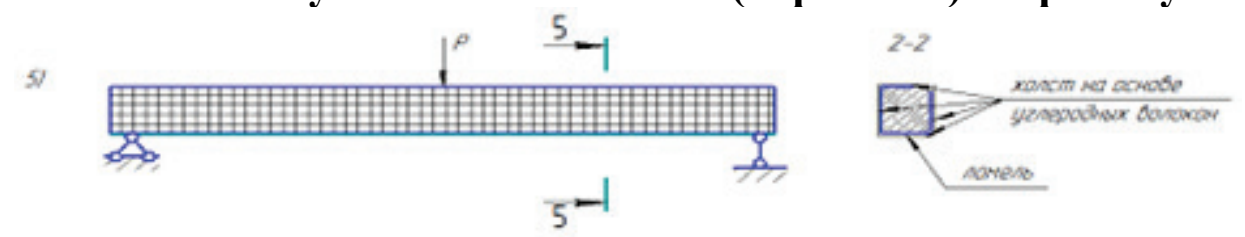

Рис.5. Схема с усилением ламелью и холстом. Серия Пу-V 
Методика усиления выполнялась в соответствие с рекомендациями концерна BASF [11]. Усиление перемычек проводили с использованием ламелей и холстов на основе однонаправленных углеродных волокон.

Испытания на изгиб проводили на 20 тонной универсальной испытательной машине. Прогибы измеряли индикаторами часового типа с ценой деления 0,01 мм. Деформации фиксировали тензометрами Аистова на базе 100 мм. При этом фиксировали деформации, как самого бетона, так и деформации ламели. Загружение образцов проводили ступенями равными $10 \%$ от предполагаемой разрушающей нагрузки. Выдержка на каждой ступени составляла по 10 - 20 минут.

\section{Результаты испытаний.}

Обобщенные результаты испытаний сведены в таблицу 1. В таблице также приведены и результаты расчета балок по методике «Руководство по усилению железобетонных конструкций композитными материалами» концерна BASF [12-14].

Разрушение всех усиленных образцов произошло от совместного действия момента и поперечной силы. Разрушение образцов усиленных на поперечную силу (рис. 3 - 5) начиналось при нагрузке близкой к 25 кН и носило плавный характер. При этом происходило снижение нагрузки до 20 кН. В последующем происходило нарастание нагрузки с внезапным разрушением (хлопок) бетона. Отрыв ламели происходил после разрушения бетона.

\section{Заключение и выводы}

1. Результаты испытаний показали, что на всех этапах загружения (вплоть до разрушения) обеспечивалась совместная работа бетона и углепластика. В местах образования трещин деформации бетона и ламелей отличались между собой не более чем на $9 \%$.

2. Напряжения в ламелях при разрушении составляли 1100 - 1200 МПа.

3. Наибольшие относительные деформации бетона сжатой зоны значительно превосходили деформаций при центральном сжатии и достигали значений $300 \ldots 360 \times 10^{-5}$.

4. В процессе испытаний высота сжатой зоны уменьшалась. Распределение фибровых деформаций в нормальном сечении было близко к линейному.

5. Усиление образцов только по нормальному сечению привело к повышению их несущей способности в 6 раз. Дополнительное усиление образцов по наклонному сечению привело к увеличению несущей способности балок до 9 раз. Значительное увеличение несущей способности балок связано и изначально низким процентом армирования.

6. Прогибы балок были пропорциональны действующей нагрузке.

7. Сравнение результатов испытаний и расчетов, выполненных по методике «Руководство по усилению железобетонных конструкций композитными материалами», дало расхождение $10 . .13 \%$ [12-14].

Результаты исследований легли в основу и были реализованы при усилении мостового сооружения в Челябинской области. 
Таблица 1.

Результаты испытаний перемычек.

Состояние плиты

\begin{tabular}{|c|c|c|}
\hline Состояние плиты & $\begin{array}{l}\text { Расчетное } \\
\text { значение }\end{array}$ & $\begin{array}{c}\text { Экспериментально } \\
\text { е значение }\end{array}$ \\
\hline \multicolumn{3}{|c|}{ Серия ПІ . Без усиления. } \\
\hline Разрушающее усилие, по моменту, кН & 4,2 & $4,0(3,8)$ \\
\hline $\begin{array}{l}\text { Разрушающее усилие по поперечной } \\
\text { силе, кН }\end{array}$ & 25,2 & 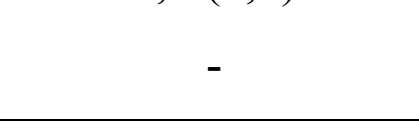 \\
\hline \multicolumn{3}{|c|}{ Разрушение по нормальному сечению } \\
\hline \multicolumn{3}{|c|}{ Серия ПуII . С усилением: одна ламель внизу LamCF 165//3000/50x1,2. } \\
\hline Разрушающее усилие, по моменту, кН & 40,7 & - \\
\hline $\begin{array}{l}\text { Разрушающее усилие по поперечной } \\
\text { силе, кН }\end{array}$ & 25,2 & - \\
\hline $\begin{array}{l}\text { Совместное действие момента и } \\
\text { поперечной силы, кН }\end{array}$ & 23,1 & $24,0(25,8)$ \\
\hline
\end{tabular}

Разрушение от совместного действия поперечной силь и момента при одновременном разрушении бетона сжатой зоньи

Серия ПуІІ. С усилением: одна ламель внизу LamCF 165|/3000/50x1,2 и наклонные ламели с шагом 50 мм .

Разрушающее усилие, по моменту, кН

Разрушающее усилие по перечной силе в

наклонном сечении, кН

Разрушение по моменту в наклонном сечении кН

\section{Разрушение от момента в наклонном сечении}

Серия ПуIV. С усилением: одна ламель внизу LamCF 165 $\mid 3000 / 50 x 1,2$ и вертикальные ламели с шагом 50 мм

Разрушающее усилие, по моменту, кН

Разрушающее усилие по перечной силе в наклонном сечении, кН

Разрушение по моменту в наклонном сечении кН

Разрушение от среза бетона между ламелями

$35.6 \quad 31,5(32,5)$

Серия ПуV. C усилением: одна ламель внизу LamCF 165/3000/50x1,2 и тканью FibCF 230|/49000.200q/5 одним слоем все сечение и двумя слоями в середине шириной 500 мм

Разрушающее усилие, по моменту, кН

Разрушающее усилие по поперечной силе, кН

Момент в наклонном сечении кН Авторская разработка

45,7

89,3

29,2

$30,2(29,2)-$

Литература:

1. Nabil F. Grace, S.B. Singh. Durability Evaluation of Carbon Fiber-Reinforced Polymer Strengthened Concrete Beams: Experimental Study and Design. ACI 
Structural Journal, January-February, 2005, p 40-53.

2. Cardolin A. Carbon Fibre Reinforced Polymers for Strengthening of Structural Elements. Division of Structural Engineering, Department of Civil and Mining Engineering, Lulea University of Technology, Sweden.2003, p. 194.

3. FRP Repair Materials and Methods. Concrete International, 2005, vol. 27, 1, p. 66.

4. Guide to Test Methods for Fiber-Reinforced Polymers (FRPs) for Reinforcing or Strengthening Concrete Structures. Concrete International, 2005, vol. 27, 1, p. 13

5. Etcheverry L. The Rehabilitation of Cooling Towers. Concrete International, 2005, vol. 27, № 1, p. 27

6. Бокарев С.А. Нелинейный анализ железобетонных изгибаемых конструкций,усиленных композитными материалами. ВестникТГАСУ,№ 2, 2010/

7. Пособие по проектированию бетонных и железобетонных конструкций из тяжелого бетона без предварительного напряжения арматуры (к СП 52-1012003). Пособие от 01.01.2005 N 52-101-2003. М.2005.

8. Пивоварова О.В., Пивоваров В.С., Варламов А.А. Испытание фрагмента сборно-монолитного перекрытия с новым шпоночным стыком Жилищное строительство 2012, №5, С.16-18.

9. Варламов А.А., Круциляк Ю.М. Эффективная система усиления конструкций //Ресурсоэнергоэффективные технологии в строительном комплексе региона. Саратов: СГТУ, 2012, С.179-182.

10. Варламов А.А., Мясников А.Л., Телешман Е.П. Изгибаемые конструкции со стеклопластиковой арматурой //Актуальные проблемы современной науки, техники и образования. -Магнитогорск: Изд-во Магнитогорск.гос. техн. ун-та им. Г.И.Носова, 2014. Т.2. С.70-73.

11. SKY-SAP2007. Проект S/W для применения комплектов усиливающих материалов системы MBrace®. Материалы на основе углепластика (FRP материалы). BASF.

12. «Руководство по усилению железобетонных конструкций композитными материалами». ООО Интераква (Чернявский В.Л., Хаютин Ю.Г., Аксельрод Е.З., Клевцов В.А., Фаткуллин Н.В.), М., НИИЖБ, 2006.

13. Guide for the Design and Construction of Externally Bonded FRP Systems for Strengthening Concrete Structures. ACI 440.2R-02. American Concrete Institute.

14. Chen, J.F. and Teng, J.C. 2003. ShearcapacityofFRPstrengthenedRCbeams: FRPrupture. JournalofStructuralEngineering, ASCE, 129 (5): 615-625

\section{References:}

1. Nabil F. Grace, S.B. Singh. Durability Evaluation of Carbon Fiber-Reinforced Polymer Strengthened Concrete Beams: Experimental Study and Design. ACI Structural Journal, JanuaryFebruary, 2005, p 40-53.

2. Cardolin A. Carbon Fibre Reinforced Polymers for Strengthening of Structural Elements. Division of Structural Engineering, Department of Civil and Mining Engineering, Lulea University of Technology, Sweden.2003, p. 194.

3. FRP Repair Materials and Methods. Concrete International, 2005, vol. 27, 1, p. 66.

4. Guide to Test Methods for Fiber-Reinforced Polymers (FRPs) for Reinforcing or 
Strengthening Concrete Structures. Concrete International, 2005, vol. 27, 1, p. 13

5. Etcheverry L. The Rehabilitation of Cooling Towers. ConcreteInternational, 2005, vol. 27, № 1 , p. 27

6. Bokarev S. A. Nonlinear analysis of reinforced concrete bending structures strengthened with composite materials. Vestnic TSCU, No. 2, 2010.

7. A manual for design of concrete and reinforced concrete structures of heavy concrete without prestress reinforcement (SP 52-101-2003)..Allowance from 01.01.2005 N 52-101-2003..M. 2005.

8. Pivovarova O. V., Pivovarov V. S. andVarlamov A. A. the Testing of the fragment prefabricated monolithic overlap with the new keyed joint. ZhilishcnoeStroitel'stvo, 2012, No. 5, Pp. 16-18

9. Varlamov A. A. andKrutilekY. M. Effective system for strengthening of structures //Resursosberegenie technology in the construction complex of the region. Saratov: SSTU, 2012,Pp. 179-182

10. Varlamov A. A., Myasnikov A. L. and E. P. Talesman Flexible construction with fiberglass reinforcement //Actual problems of modern science, and technology education. Magnitogorsk: Publishing house Magnitogorsk.,MSTU, 2014.-Vol. 2. -P. 70-73.

11. SKY-SAP2007. Project S/W for the application of sets of reinforcing materials system MBrace ${ }^{\circledR}$. Materials based on CFRP (FRP materials). BASF.

12.Manual strengthening reinforced concrete structures with composite materials. OOO Interakva (Chernyavsky V. L., J. G. Khayutin, E. Z. Axelrod, Klevtsov V. A. and Fatkullin N. In.), M., NIIZHB, 2006.

13. Guide for the Design and Construction of Externally Bonded FRP Systems for Strengthening Concrete Structures. ACI 440.2R-02. American Concrete Institute.

14. Chen, J.F. and Teng, J.C. 2003. Shear capacity of FRP strengthened RC beams: FRP rupture. JournalofStructuralEngineering, ASCE, 129 (5): 615-625

Abstract. This article considers the problem of reinforcement in defective concrete and reinforced concrete structures. Noted that one of the best systems strengthening is a system MBrace of BASF.In the experimental part of this article presents the results of the tests. To assess the possibility of strengthening of flexible elements made of local materials, were completed testing of reinforced concrete lintels. It was made five batches of samples. The first batch of samples was made without amplification. The second batch with the amplification of only the stretched part of the section. The third and fourth pariah with the strengthening of the lamellae normal and oblique section. The last batch was reinforced slats and canvas. In this part of the work shows the results of the tests and Revealed a new design scheme of destruction.The following section presents the results of calculations of reinforced lintels. The calculation results are presented in the table. The comparison of calculation results with test results. The analysis of the obtained results/Based on the analysis results the conclusion is made on possibility of use of the reinforcement system in reinforced concrete structures. shear.

Keywords: the gain jumpers,amplification the system MBrace, CFRP, test bending, test

Статья отправлена: 16.06.2018 г. С Варламов А.А., Гаврилов В.Б., Веденёв А.В. 